\title{
Infrared and Raman spectroscopic characterization of the phosphate mineral fairfieldite $-\mathrm{Ca}_{2}\left(\mathrm{Mn}^{2+}, \mathrm{Fe}^{2+}\right)_{2}\left(\mathrm{PO}_{4}\right)_{2} \cdot 2\left(\mathrm{H}_{2} \mathrm{O}\right)$
}

\author{
Ray L. Frost ${ }^{\mathrm{a}, *}$, Yunfei Xi ${ }^{\mathrm{a}}$, Ricardo Scholz ${ }^{\mathrm{b}}$, Fernanda Maria Belotti ${ }^{\mathrm{c}}$, Andres Lopez ${ }^{\mathrm{a}}$

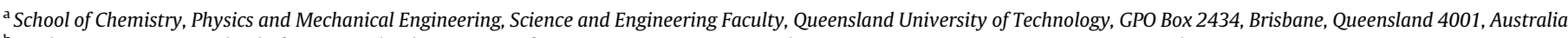 \\ ${ }^{\mathrm{b}}$ Geology Department, School of Mines, Federal University of Ouro Preto, Campus Morro do Cruzeiro, Ouro Preto, MG 35,400-00, Brazil \\ ${ }^{\mathrm{c}}$ Federal University of Itajubá, Campus Itabira, Itabira, MG 35,903-087, Brazil
}

\section{H I G H L I G H T S}

- We have studied fairfieldite from Cigana mine of the Eastern Brazilian Pegmatite Province in Minas Gerais.

- The chemical formula was determined using an electron probe.

- Vibrational spectroscopy was used to determine the structure.

- Multiple bands in antisymmetric stretching spectral region provide evidence of symmetry reduction of the phosphate anion.

\section{A R T I C L E I N F O}

\section{Article history:}

Received 28 November 2012

Accepted 8 January 2013

Available online 17 January 2013

\section{Keywords:}

Raman spectroscopy

Fairfieldite

Infrared spectroscopy

Phosphate

Pegmatite
G R A P H I C A L A B S T R A C T

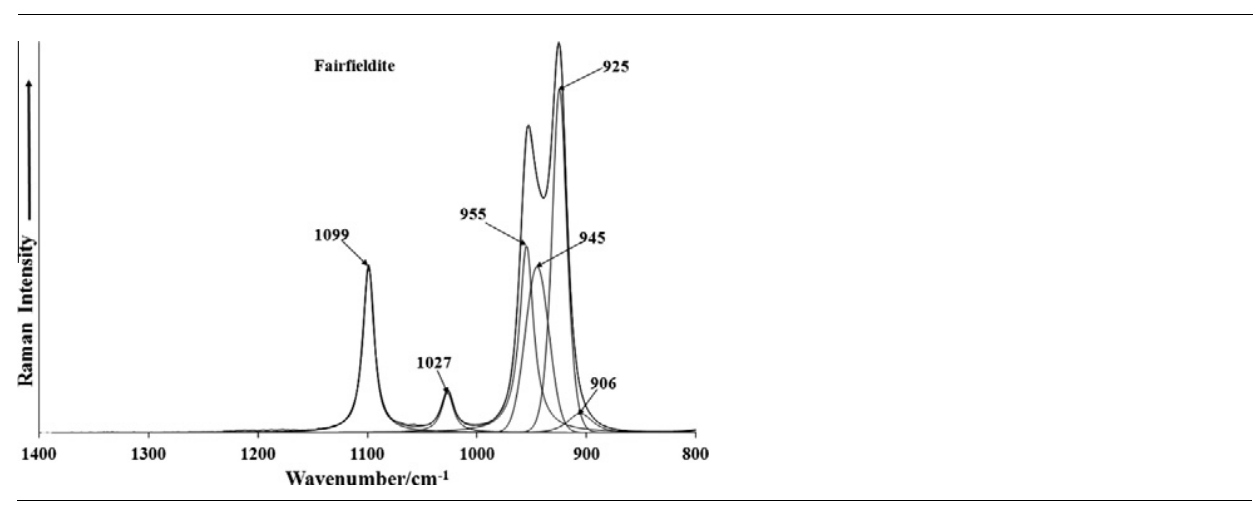

\section{A B S T R A C T}

Raman spectroscopy complimented with infrared spectroscopy has been used to determine the molecular structure of the phosphate mineral fairfieldite. The Raman phosphate $\left(\mathrm{PO}_{4}\right)^{3-}$ stretching region shows strong differences between the fairfieldite phosphate minerals which is attributed to the cation substitution for calcium in the structure. In the infrared spectra complexity exists with multiple $\left(\mathrm{PO}_{4}\right)^{2-}$ antisymmetric stretching vibrations observed, indicating a reduction of the tetrahedral symmetry. This loss of degeneracy is also reflected in the bending modes. Strong Raman bands around $600 \mathrm{~cm}^{-1}$ are assigned to $v_{4}$ phosphate bending modes. Multiple bands in the $400-450 \mathrm{~cm}^{-1}$ region assigned to $v_{2}$ phosphate bending modes provide further evidence of symmetry reduction of the phosphate anion. Three broadbands for fairfieldite are found at 3040,3139 and $3271 \mathrm{~cm}^{-1}$ and are assigned to $\mathrm{OH}$ stretching bands. By using a Libowitzky empirical equation hydrogen bond distances of 2.658 and $2.730 \AA$ are estimated. Vibrational spectroscopy enables aspects of the molecular structure of the fairfieldite to be ascertained. (c) 2013 Elsevier B.V. All rights reserved.

\section{Introduction}

The fairfieldite mineral group are triclinic arsenates and phosphates of the general formula $\mathrm{Ca}_{2} \mathrm{~B}\left(\mathrm{XO}_{4}\right)_{2} \cdot 2 \mathrm{H}_{2} \mathrm{O}$ where $\mathrm{B}$ is $\mathrm{Co}$, $\mathrm{Fe}^{2+}, \mathrm{Mg}, \mathrm{Mn}, \mathrm{Ni}, \mathrm{Zn}$ and $\mathrm{X}$ is either As or P [1-6]. The minerals form two subgroups based upon whether the anion is phosphate or arsenate. Minerals in this group include cassidyite $\left[\mathrm{Ca}_{2}(\mathrm{Ni}, \mathrm{Mg})\right.$

\footnotetext{
* Corresponding author. Tel.: +61 73138 2407; fax: +61 731381804 .

E-mail address: r.frost@qut.edu.au (R.L. Frost).
}

$\left.\left(\mathrm{PO}_{4}\right)_{2} \cdot 2 \mathrm{H}_{2} \mathrm{O}\right]$, collinsite $\left[\mathrm{Ca}_{2}\left(\mathrm{Mg}, \mathrm{Fe}^{2+}\right)\left(\mathrm{PO}_{4}\right)_{2} \cdot 2 \mathrm{H}_{2} \mathrm{O}\right]$, fairfieldite $\left[\mathrm{Ca}_{2}\left(\mathrm{Mn}, \mathrm{Fe}^{2+}\right)\left(\mathrm{PO}_{4}\right)_{2} \cdot 2 \mathrm{H}_{2} \mathrm{O}\right]$, gaitite $\left[\mathrm{Ca}_{2} \mathrm{Zn}\left(\mathrm{AsO}_{4}\right)_{2} \cdot 2 \mathrm{H}_{2} \mathrm{O}\right]$, messelite $\left[\mathrm{Ca}_{2}\left(\mathrm{Mn}^{2+}, \mathrm{Fe}^{2+}\right)\left(\mathrm{PO}_{4}\right)_{2} \cdot 2 \mathrm{H}_{2} \mathrm{O}\right]$, parabrandite $\left[\mathrm{Ca}_{2} \mathrm{Mn}^{2+}\left(\mathrm{AsO}_{4}\right)_{2} \cdot 2 \mathrm{H}_{2} \mathrm{O}\right]$, roselite-beta $\left[\mathrm{Ca}_{2} \mathrm{Co}\left(\mathrm{AsO}_{4}\right)_{2} \cdot 2 \mathrm{H}_{2} \mathrm{O}\right]$, and talmessite $\left[\mathrm{Ca}_{2} \mathrm{Mg}\left(\mathrm{AsO}_{4}\right)_{2}\right.$. $2 \mathrm{H}_{2} \mathrm{O}$ ]. The minerals form solid solutions for example the collinsite-fairfieldite series. Many of these minerals are found in Australia [7-9].

The structure of the fairfieldite group minerals is dominated by the chains of tetrahedra $\left(\mathrm{XO}_{4}\right)$ and octahedra $\left[\mathrm{B}-\mathrm{O}_{4}\left(\mathrm{H}_{2} \mathrm{O}\right)_{2}\right]$ which parallel the $C$ axis. The fairfieldite group crystallizes in the triclinic 


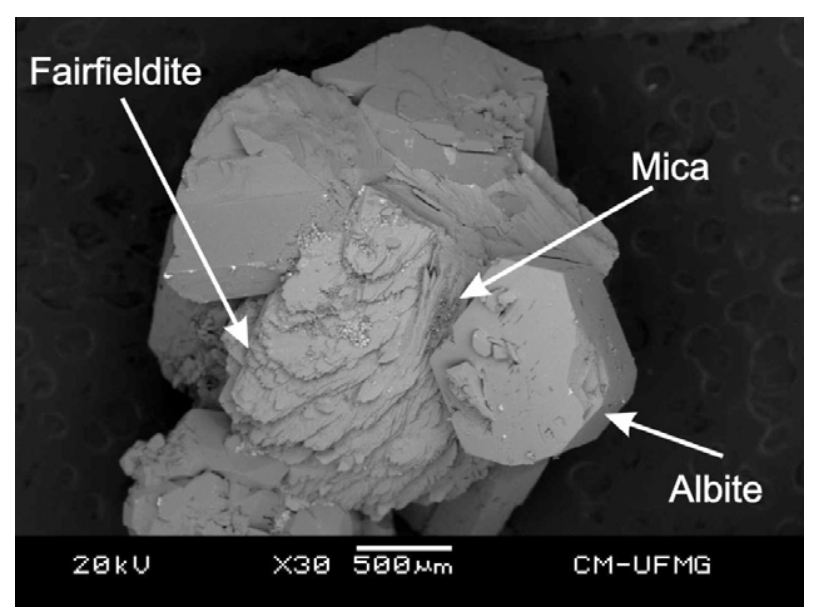

Fig. 1. A backscattered electron image (BSI) of a fairfieldite single crystal up to $0.5 \mathrm{~mm}$ in length.

space group $P \overline{1}$. The cation octahedra are compressed resulting in disorder of the chains. This affects the hydrogen bonding of the water in the structure. The amount of published data on the Raman spectra of mineral phosphates is limited [10-14]. There has been limited published data on the fairfieldite mineral group [15-17]. The Raman spectra of the hydrated hydroxy phosphate minerals have not been reported. In aqueous systems, Raman spectra of phosphate oxyanions show a symmetric stretching mode $\left(v_{1}\right)$ at $938 \mathrm{~cm}^{-1}$, the antisymmetric stretching mode $\left(v_{3}\right)$ at $1017 \mathrm{~cm}^{-1}$, the symmetric bending mode $\left(v_{2}\right)$ at $420 \mathrm{~cm}^{-1}$ and the $v_{4}$ mode at $567 \mathrm{~cm}^{-1}[12,13,18]$. S.D. Ross in Farmer [19] (p404) listed some well-known minerals containing phosphate which were either hydrated or hydroxylated or both [19]. Farmer (p392) listed the band positions of collinsite, one of the fairfieldite minerals. The $v_{1}$ $\left(\mathrm{PO}_{4}\right)^{3-}$ symmetric stretching vibration was listed as 945 and $920 \mathrm{~cm}^{-1}$; the $v_{3}\left(\mathrm{PO}_{4}\right)^{3-}$ symmetric stretching vibrations as 1112 and $1000 \mathrm{~cm}^{-1}$, the $v_{4}$ bending modes as 577 and $562 \mathrm{~cm}^{-1}$. A band at $770 \mathrm{~cm}^{-1}$ was observed but not assigned. In comparison the value for the $v_{1}$ symmetric stretching vibration of $\mathrm{PO}_{4}$ units as determined by infrared spectroscopy was given as $930 \mathrm{~cm}^{-1}$ (augelite), $940 \mathrm{~cm}^{-1}$ (wavellite), $970 \mathrm{~cm}^{-1}$ (rockbridgeite), $995 \mathrm{~cm}^{-1}$ (dufrenite) and $965 \mathrm{~cm}^{-1}$ (beraunite). The position of the symmetric stretching vibration is mineral dependent and a function of the cation and crystal structure. The fact that the symmetric stretching mode is observed in the infrared spectrum affirms a reduction in symmetry of the $\mathrm{PO}_{4}$ units.

Fairfieldite is a common calcium and manganese hydrate phosphate mineral in granitic pegmatites. The general chemical formula of fairfieldite is expressed by $\mathrm{Ca}\left(\mathrm{Mn}^{2+}, \mathrm{Fe}^{2+}\right)\left(\mathrm{PO}_{4}\right)_{2} \cdot 2\left(\mathrm{H}_{2} \mathrm{O}\right)$ [20]. The mineral forms a series with collinsite, its $\mathrm{Mg}^{2+}$ analogous, in substitution to manganese. Fairfieldite belongs to the homonymous group that includes a number of phosphates and arsenates such as talmessite, messelite, gaitite and collinsite among others. The

Table 1

Chemical composition of fairfieldite from Cigana pegmatite, Minas Gerais. $\mathrm{H}_{2} \mathrm{O}$ calculated by stoichiometry on the basis of ideal formula.

\begin{tabular}{|c|c|c|c|c|c|c|c|c|c|c|c|c|}
\hline Sample & $\mathrm{P}_{2} \mathrm{O}_{5}$ & $\mathrm{CaO}$ & $\mathrm{MnO}$ & $\mathrm{FeO}$ & $\mathrm{MgO}$ & $\mathrm{Na}_{2} \mathrm{O}$ & $\mathrm{Al}_{2} \mathrm{O}_{3}$ & $\mathrm{SrO}$ & $\mathrm{CuO}$ & $\mathrm{ZrO}$ & $\mathrm{H}_{2} \mathrm{O}$ & Total \\
\hline SAA-099 & 38.64 & 30.53 & 10.93 & 2.19 & 3.69 & 0.03 & 0.01 & 0.02 & 0.02 & 0.02 & 9.97 & 96.09 \\
\hline Fairfieldite $^{*}$ & 39.32 & 31.07 & 9.87 & - & - & - & - & - & - & - & 9.97 & 100.00 \\
\hline \multirow[t]{2}{*}{ Collinsite $^{*}$} & 42.96 & 33.95 & - & - & 12.20 & - & - & - & - & - & 10.90 & 100.00 \\
\hline & $\mathrm{P}$ & $\mathrm{Ca}$ & Mn & $\mathrm{Fe}$ & $\mathrm{Mg}$ & $\mathrm{Na}$ & $\mathrm{Al}$ & $\mathrm{Sr}$ & $\mathrm{Cu}$ & $\mathrm{Zr}$ & $\mathrm{H}$ & Total \\
\hline SAA-099 & 1.99 & 1.99 & 0.56 & 0.11 & 0.33 & 0.00 & 0.00 & 0.00 & 0.00 & 0.00 & 2.02 & 7.00 \\
\hline Fairfieldite $^{*}$ & 2.00 & 2.00 & 1.00 & 0.00 & 0.00 & 0.00 & 0.00 & 0.00 & 0.00 & 0.00 & 2.00 & 7.00 \\
\hline Collinsite ${ }^{*}$ & 2.00 & 2.00 & 0.00 & 0.00 & 1.00 & 0.00 & 0.00 & 0.00 & 0.00 & 0.00 & 2.00 & 7.00 \\
\hline
\end{tabular}

" Calculated by stoichimetry acording to ideal formula of end members.

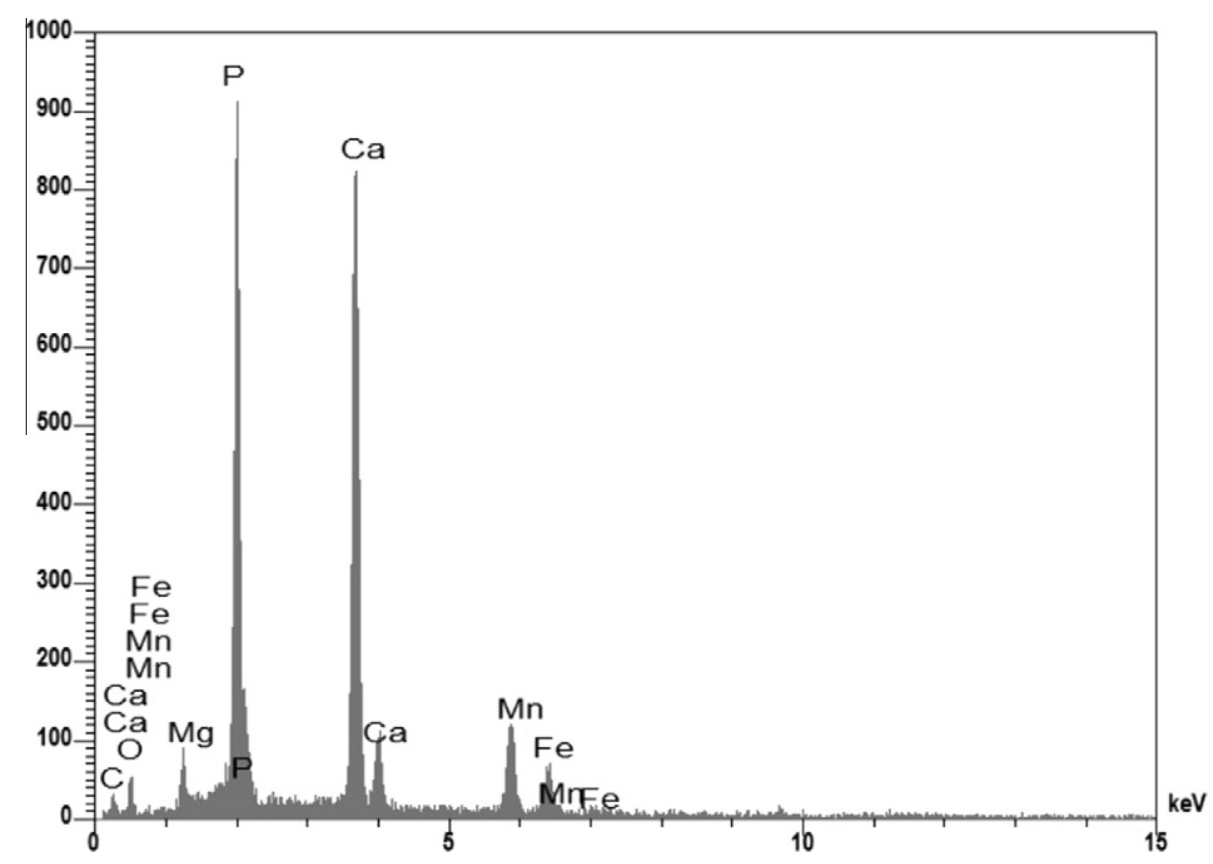

Fig. 2. EDS analysis of fairfieldite. 
mineral was first described by Brush and Dana in 1879 from Fairfield County, Connecticut, USA [21]. Other occurrences were later described in the Cigana mine, Brazil [22]; Tanco mine, Canada [23] and Barroso-Alvão pegmatite, Portugal [24]. The crystal structure of fairfieldite was refined by Fanfani et al. [3]. The mineral crystallizes in the triclinic crystal system, space group $P \overline{1}$ with unit cell parameter $a=5.78 \AA, b=6.57 \AA, c=5.48 \AA, \alpha=102.08^{\circ}$, $\beta=108.71^{\circ}$ and $\gamma=90.09^{\circ}$.

Studies concerning the mineralogy of phosphates of the fairfieldite group minerals are rare in literature [25] and to the best knowledge of the authors, data about vibrational spectroscopic characterization are restricted to the database of the University of Arizona (rruff.info), however no interpretation is given. No Raman spectroscopic investigation of these phosphate phases related to the leucophosphite group has been published. However, in recent years, the application of spectroscopic techniques to understand the structure of phosphates has been increasing [2628]. In this work, samples of fairfieldite from the Cigana pegmatite, located in the municipality of Conselheiro Pena, Brazil have been selected for study. These studies include chemistry with analysis via electron microprobe (EMP) in the WDS mode and the spectroscopic characterization of the structure with infrared and Raman.

\section{Experimental}

\section{Samples description and preparation}

The fairfieldite sample studied in this work was collected from the Cigana mine (also named as Jocão mine), a lithium-bearing pegmatite located in the Conselheiro Pena Pegmatite district (CPD), one of the eleven metallogenetic subdivisions of the Eastern Brazilian Pegmatite Province (EBP) in Minas Gerais [29]. The Cigana mine is an important source for rare and unusual phosphate and industrial minerals (microcline, triphylite and spodumene)

In the Cigana mine, white crystals of fairfieldite and aggregates up to $3.0 \mathrm{~mm}$ occur in association with pyrite, quartz, albite and muscovite. The collected sample was incorporated to the collection of the Geology Department of the Federal University of Ouro Preto, Minas Gerais, Brazil, with sample code SAA-099. The sample was gently crushed and the associated minerals were removed under
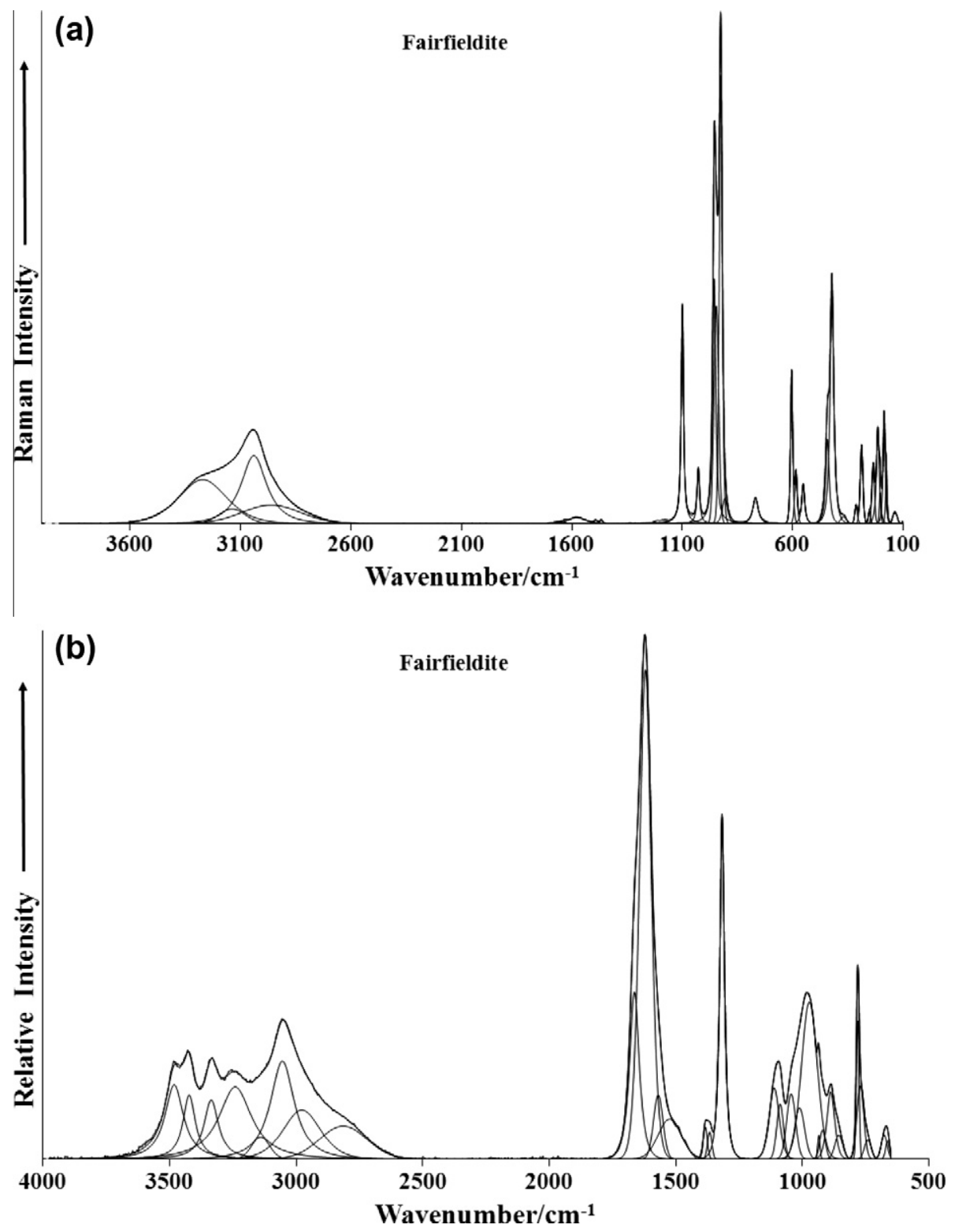

Fig. 3. (a) Raman spectrum of fairfieldite over the $100-4000 \mathrm{~cm}^{-1}$ spectral range and (b) infrared spectrum of fairfieldite over the $500-4000 \mathrm{~cm}^{-1}$ spectral range. 
a stereomicroscope Leica MZ4. Scanning electron microscopy (SEM) was applied to support the chemical characterization and indicate the elements to be analyzed by EMP.

\section{Scanning electron microscopy (SEM)}

Experiments and analyses involving electron microscopy were performed in the Center of Microscopy of the Universidade Federal de Minas Gerais, Belo Horizonte, Minas Gerais, Brazil (http:// www.microscopia.ufmg.br).

Fairfieldite crystal aggregate was coated with a $5 \mathrm{~nm}$ layer of evaporated Au. Secondary Electron and Backscattering Electron images were obtained using a JEOL JSM-6360LV equipment. Qualitative and semi-quantitative chemical analysis in the EDS mode were performed with a ThermoNORAN spectrometer model Quest and was applied to support the mineral characterization.

Electron microprobe analysis (EMP)

The quantitative chemical analysis of fairfieldite single crystal was carried via EMP. The chemical analysis was carried out with a JEOL JXA-8230 spectrometer from the Laboratório de Micross- onda Eletrônica, Instituto de Geociências, Universidade de Brasília (IG/UnB), Brasília. For each selected element was used the following standards: Fe and Mg - Olivin, Mn - Rodhonite, P and Ca - Apatite Artimex, Al - Corundum, Na - Albite, $\mathrm{Sr}$ - Celestite, $\mathrm{Cu}$ Chalcopyrite and $\mathrm{Zr}$ - Baddeleyite. The epoxy embedded fairfieldite crystal was polished in the sequence of $9 \mu \mathrm{m}, 6 \mu \mathrm{m}$ and $1 \mu \mathrm{m}$ diamond paste MetaDI ${ }^{\circledR}$ II Diamond Paste - Buhler, using water as a lubricant, with a semi-automatic MiniMet ${ }^{\circledR} 1000$ Grinder-Polisher - Buehler. Finally, the epoxy embedded sample was coated with a thin layer of evaporated carbon. The electron probe microanalysis in the WDS (wavelength dispersive spectrometer) mode was obtained at $15 \mathrm{kV}$ accelerating voltage and beam current of $10 \mathrm{nA}$. Chemical formula was calculated on the basis of seven oxygen atoms $\left(\mathrm{O}\right.$ and $\left.\mathrm{H}_{2} \mathrm{O}\right)$.

\section{Raman microprobe spectroscopy}

Crystals of fairfieldite were placed on a polished metal surface on the stage of an Olympus BHSM microscope, which is equipped with $10 \times, 20 \times$, and $50 \times$ objectives. The microscope is part of a Renishaw 1000 Raman microscope system, which also includes a
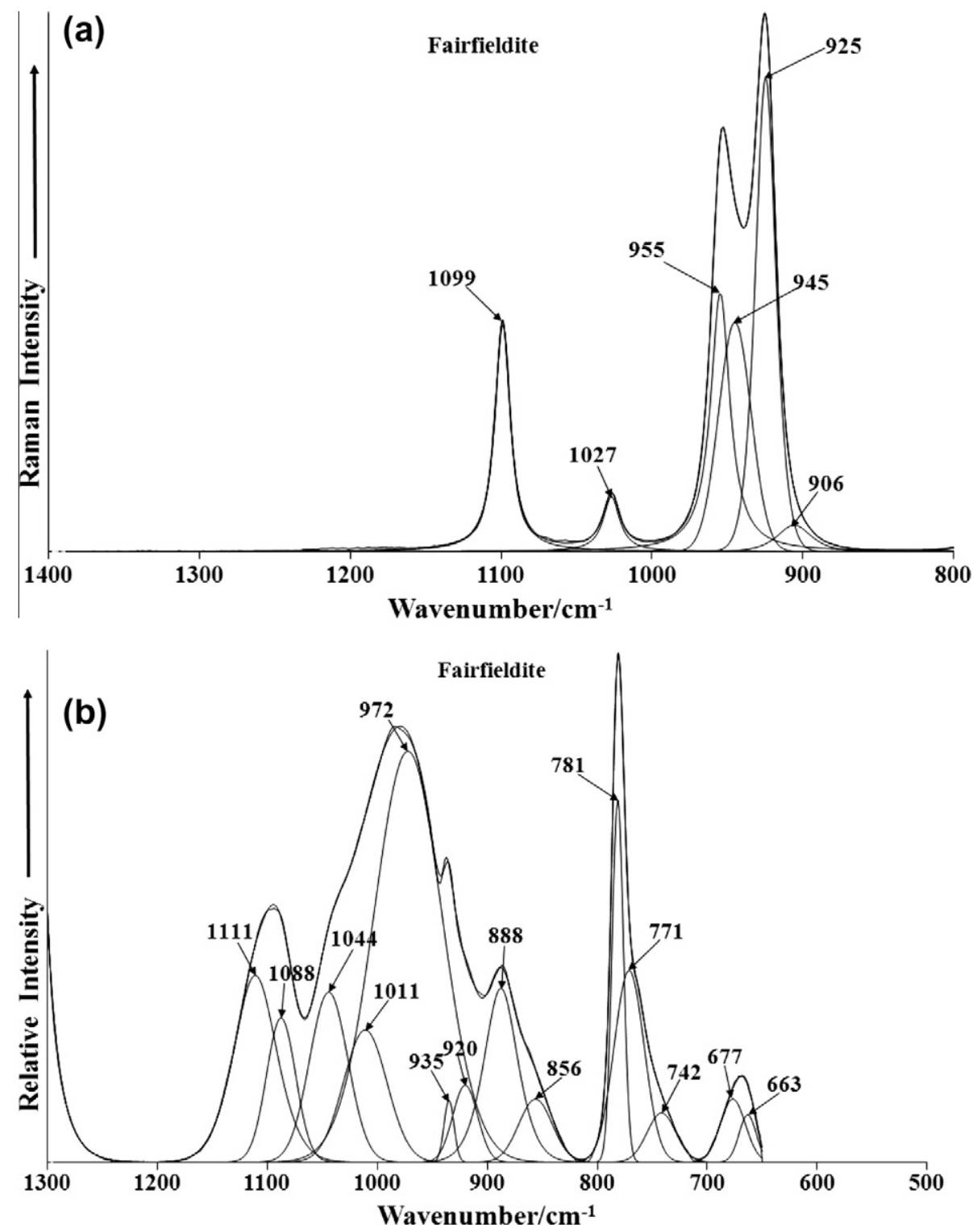

Fig. 4. (a) Raman spectrum of fairfieldite over the $800-1400 \mathrm{~cm}^{-1}$ spectral range and (b) infrared spectrum of fairfieldite over the $500-1300 \mathrm{~cm}{ }^{-1}$ spectral range. 
monochromator, a filter system and a CCD detector (1024 pixels). The Raman spectra were excited by a Spectra-Physics model 127 He-Ne laser producing highly polarized light at $633 \mathrm{~nm}$ and collected at a nominal resolution of $2 \mathrm{~cm}^{-1}$ and a precision of $\pm 1 \mathrm{~cm}^{-1}$ in the range between 200 and $4000 \mathrm{~cm}^{-1}$. Repeated acquisitions on the crystals using the highest magnification $(50 \times)$ were accumulated to improve the signal to noise ratio of the spectra. Raman Spectra were calibrated using the $520.5 \mathrm{~cm}^{-1}$ line of a silicon wafer. The Raman spectrum of at least 10 crystals was collected to ensure the consistency of the spectra.

\section{Infrared spectroscopy}

Infrared spectra were obtained using a Nicolet Nexus 870 FTIR spectrometer with a smart endurance single bounce diamond ATR cell. Spectra over the $4000-525 \mathrm{~cm}^{-1}$ range were obtained by the co-addition of 128 scans with a resolution of $4 \mathrm{~cm}^{-1}$ and a mirror velocity of $0.6329 \mathrm{~cm} / \mathrm{s}$. Spectra were co-added to improve the signal to noise ratio. The infrared spectra are given in the supplementary information.
Spectral manipulation such as baseline correction/adjustment and smoothing were performed using the Spectracalc software package GRAMS (Galactic Industries Corporation, NH, USA). Band component analysis was undertaken using the Jandel 'Peakfit' software package that enabled the type of fitting function to be selected and allows specific parameters to be fixed or varied accordingly. Band fitting was done using a Lorentzian-Gaussian cross-product function with the minimum number of component bands used for the fitting process. The Gaussian-Lorentzian ratio was maintained at values greater than 0.7 and fitting was undertaken until reproducible results were obtained with squared correlations of $r^{2}$ greater than 0.995 .

\section{Results and discussion}

\section{Chemical characterization}

The SEM image of fairfieldite sample studied in this work is shown in Fig. 1. Fairfieldite crystal aggregates shows tabular form. The mineral occurs in association with albite and microcrystals of
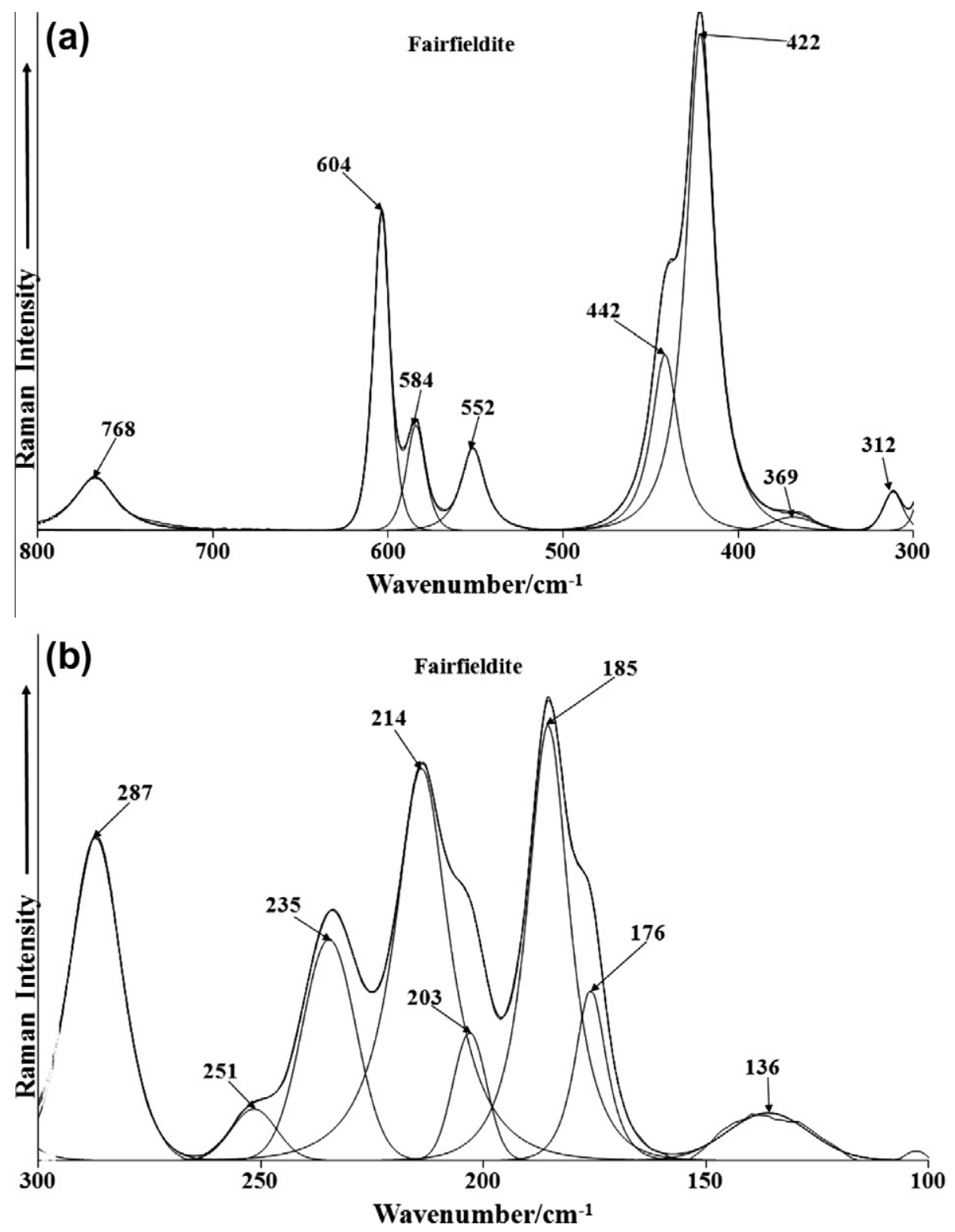

Fig. 5. (a) Raman spectrum of fairfieldite over the $300-800 \mathrm{~cm}^{-1}$ spectral range and (b) Raman spectrum of fairfieldite over the $100-300 \mathrm{~cm}-1$ spectral range. 
mica. Qualitative chemical analysis shows Ca and Mn phosphate with minor amounts of $\mathrm{Mg}$ and Fe (Fig. 2). The quantitative chemical analysis of fairfieldite is presented in Table $1 . \mathrm{H}_{2} \mathrm{O}$ content was calculated by stoichiometry and the chemical formula was calculated on the basis of $7 \mathrm{O}$ atoms $\left(\mathrm{O}\right.$ and $\left.\mathrm{H}_{2} \mathrm{O}\right)$. The chemical formula can be expressed as: $(\mathrm{Ca})_{1.99}\left(\mathrm{Mn}_{0.56} \mathrm{Mg}_{0.33}\right.$ $\left.\mathrm{Fe}_{0.11}\right)_{\sum 1.00}\left(\mathrm{PO}_{4}\right)_{1.99} \cdot 2.02\left(\mathrm{H}_{2} \mathrm{O}\right)$.

\section{Vibrational spectroscopy}

\section{Factor group analysis}

In the crystal structure of the fairfieldite-type minerals there are four phosphate units in the unit cell. These are of space group $\mathrm{C} 2 / \mathrm{m}(\mathrm{Z}=2)$, therefore there exists one formula unit per primitive unit cell, thus 37 atoms in the primitive unit cell.

$3 n-3 \rightarrow 3 * 37-3=108$ normal modes of vibrations made up of 18 internal phosphate modes +24 internal water modes +69 lattice modes- 3 translations equalling 108 modes of vibration. It is therefore predicted that there are 18 vibrationally active modes for the $\mathrm{PO}_{4}$ internal modes of phosphate in the fairfieldite structure,

$$
\begin{aligned}
& v_{1} 1 \operatorname{Raman}\left(A_{g}\right), 1 \operatorname{IR}\left(B_{u}\right) \\
& v_{2} 2 \operatorname{Raman}\left(A_{g}, B_{g}\right), 2 \operatorname{IR}\left(A_{u}, B_{u}\right) \\
& v_{3} 3 \operatorname{Raman}\left(2 A_{g}, B_{g}\right), 3 \operatorname{IR}\left(A_{u}, 2 B_{u}\right) \\
& v_{4} 3 \operatorname{Raman}\left(2 A_{g}, B_{g}\right), 3 \operatorname{IR}\left(A_{u}, 2 B_{u}\right)
\end{aligned}
$$

For water, it is predicted that there are 24 vibrationally active internal modes of water, eight Raman active stretch $\left(4 \mathrm{~A}_{\mathrm{g}}, 4 \mathrm{~B}_{\mathrm{g}}\right)$, eight IR active stretch $\left(4 \mathrm{~A}_{\mathrm{u}}, 4 \mathrm{~B}_{\mathrm{u}}\right)$, four Raman active bends $\left(2 \mathrm{~A}_{\mathrm{g}}\right.$, $\left.2 B_{g}\right)$, four IR active bends $\left(2 A_{u}, 2 B_{u}\right)$. The irreducible representation for the entire structure of the lattice vibrations of the vivianite phosphates is $\Gamma=16 \mathrm{~A}_{\mathrm{u}}+17 \mathrm{~B}_{\mathrm{u}}+15 \mathrm{~A}_{\mathrm{g}}+15 \mathrm{~B}_{\mathrm{g}}$ ignoring translational modes.

\section{Spectroscopy}

The spectra of fairfieldite over the complete wavenumber range in the Raman and infrared spectra are provided in Fig. 3. These
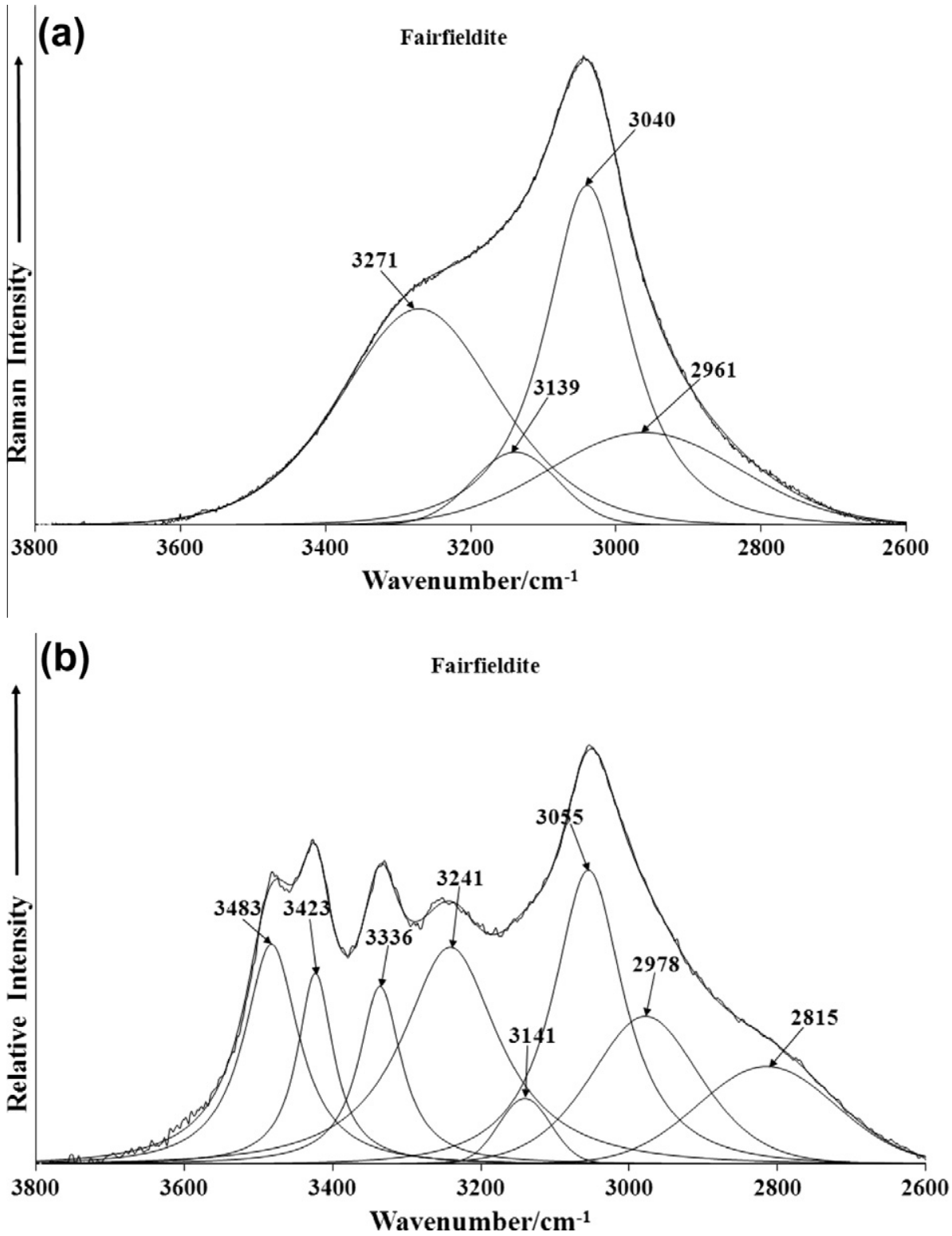

Fig. 6. (a) Raman spectrum of fairfieldite over the $2600-4000 \mathrm{~cm}^{-1}$ spectral range and (b) infrared spectrum of fairfieldite over the $2600-4000 \mathrm{~cm}^{-1}$ spectral range. 
figures show the position and the relative intensities of the bands in the Raman and infrared spectrum of fairfieldite. The Raman spectrum over the $100-4000 \mathrm{~cm}^{-1}$ spectral range is given in Fig. 3a. It is apparent that there are large parts of the spectrum where no intensity is observed. Therefore, the spectrum is subdivided into subsections depending upon the type of vibration being studied. The infrared spectrum over the $500-4000 \mathrm{~cm}^{-1}$ spectral range is displayed in Fig. 3b.

The Raman spectrum of fairfieldite over the $800-1400 \mathrm{~cm}^{-1}$ spectral range is provided in Fig. 4a. Intense Raman bands are observed at 925 and $955 \mathrm{~cm}^{-1}$ and are assigned to the $\mathrm{PO}_{4}^{3-}$ symmetric stretching mode. The observation of two symmetric stretching modes supports the concept that the phosphate units in the fairfieldite structure are not equivalent.

The Raman bands at 1027 and $1099 \mathrm{~cm}^{-1}$ are assigned to the $\mathrm{PO}_{4}^{3-}$ antisymmetric stretching mode.

The infrared spectrum in the $500-1300 \mathrm{~cm}^{-1}$ spectral range is reported in Fig. 4a. The spectrum displays complexity with a number of overlapping bands. Principal infrared bands in the $\mathrm{PO}_{4}^{3-}$ stretching region are observed at 888, 920, 972, 1011, 1044, 1088 and $1111 \mathrm{~cm}^{-1}$. The latter four bands may be attributed to the $\mathrm{PO}_{4}^{3-}$ antisymmetric stretching modes whereas the low intensity bands at 920 and $930 \mathrm{~cm}^{-1}$ may be ascribed to the $\mathrm{PO}_{4}^{3-}$ symmetric stretching mode.

The Raman spectra of fairfieldite in the $300-800 \mathrm{~cm}^{-1}$ spectral; range and in the $100-300 \mathrm{~cm}^{-1}$ spectral range are shown in Fig. 5. The Raman bands at 552, 584 and $604 \mathrm{~cm}^{-1}$ are assigned to the $v_{4}$ $\mathrm{PO}_{4}^{3-}$ bending modes whereas the Raman bands at 422 and $442 \mathrm{~cm}^{-1}$ are assigned to the $v_{2} \mathrm{PO}_{4}^{3-}$ bending modes. The low intensity infrared bands at 663 and $677 \mathrm{~cm}^{-1}$ are assigned to the $\mathrm{PO}_{4}^{3-} \quad v_{4}$ bending modes. The low intensity Raman band at $312 \mathrm{~cm}^{-1}$ is attributed to a M-O stretching vibration and the band at $768 \mathrm{~cm}^{-1}$ is assigned to a water librational mode. Such a band is of low intensity in the Raman spectrum but shows considerable more intensity in the infrared spectrum (Fig. 4b). Strong infrared bands are found at 771 and $781 \mathrm{~cm}^{-1}$ which are attributed to this vibrational mode. In the far low wavenumber region principal Raman bands are observed at 176, 185, 214, 235 and $287 \mathrm{~cm}^{-1}$. These bands are due to external vibrations and may be simply described as lattice vibrations.
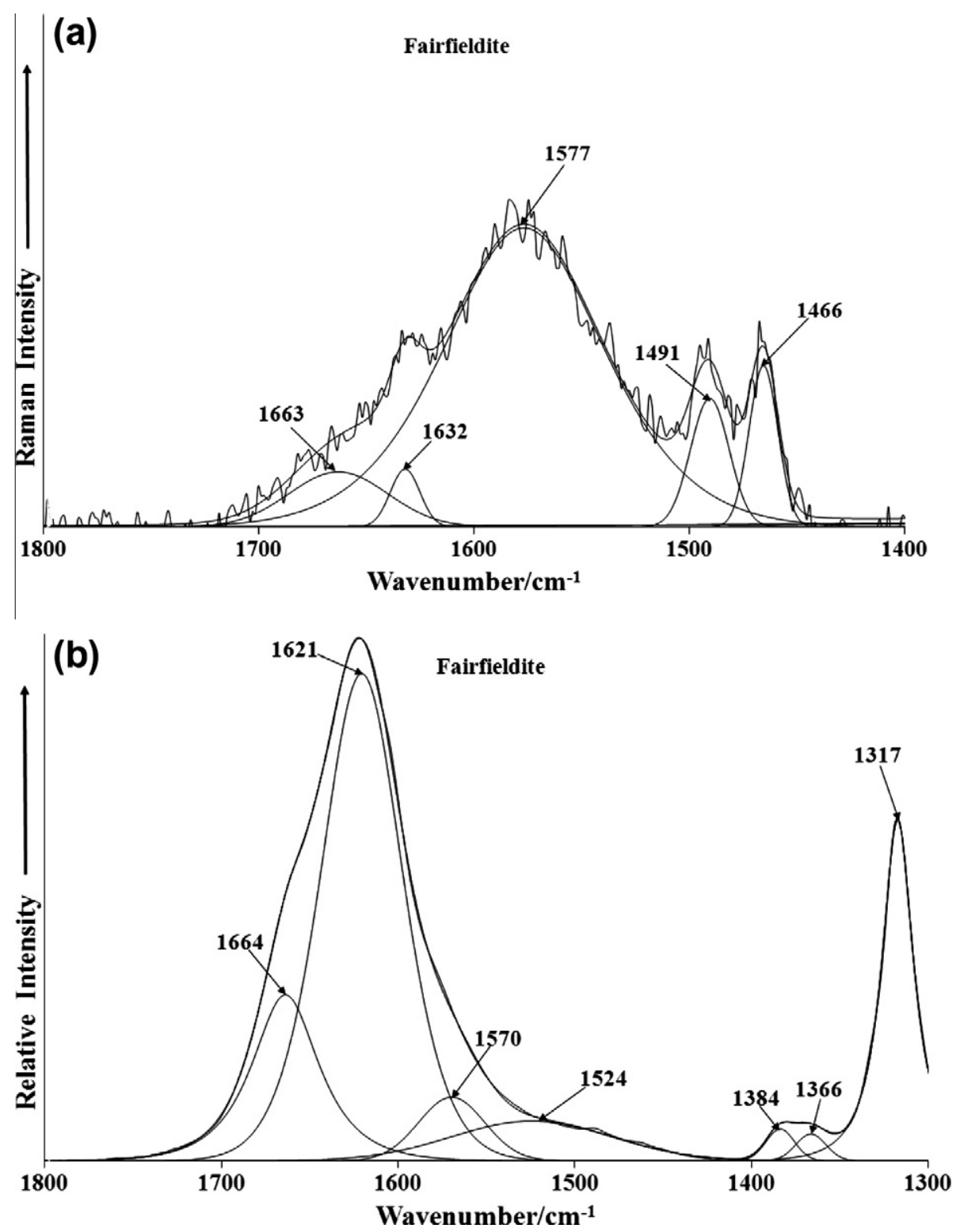

Fig. 7. (a) Raman spectrum of fairfieldite over the $1300-1800 \mathrm{~cm}^{-1}$ spectral range and (b) infrared spectrum of fairfieldite over the $1300-1800 \mathrm{~cm}{ }^{-1}$ spectral range. 
The Raman spectrum and the infrared spectrum of fairfieldite in the $2600-3800 \mathrm{~cm}^{-1}$ spectral region is shown in Fig. 6. The Raman spectrum displays principal bands at 3040 and $3271 \mathrm{~cm}^{-1}$ assigned to water stretching vibrations. The infrared spectrum shows greater complexity with a series of overlapping bands. The main infrared bands are observed at 3055, 3241, 3336, 3423 and $3483 \mathrm{~cm}^{-1}$ and are assigned to water stretching vibrations.

Studies have shown a strong correlation between $\mathrm{OH}$ stretching frequencies and both the $\mathrm{O} \ldots \mathrm{O}$ bond distances and with the $\mathrm{H} \ldots \mathrm{O}$ hydrogen bond distances [30-33]. The elegant work of Libowitzky showed that a regression function could be employed relating the above correlations with regression coefficients better than 0.96 [34]. The three Raman bands at 3040, 3149 and $3271 \mathrm{~cm}^{-1}$ enable calculations of the hydrogen bond distances of 2.658, 2.684 and $2.7303 \AA$. The six OH stretching vibrations in the infrared spectra of fairfieldite enable the calculation of predicted hydrogen bond distances of $2.6135 \AA\left(2815 \mathrm{~cm}^{-1}\right), 2.6623 \AA\left(3055 \mathrm{~cm}^{-1}\right), 2.7185 \AA$ $\left(3241 \mathrm{~cm}^{-1}\right), 2.760 \AA\left(3336 \mathrm{~cm}^{-1}\right), 2.8151 \AA\left(3423 \mathrm{~cm}^{-1}\right), 2.8730 \AA$ $\left(3483 \mathrm{~cm}^{-1}\right)$. It is noted that there is a wide range of hydrogen bond distances. This variation contributes to the stability of the mineral. For roselite, hydrogen bond distances of 2.75 and $2.67 \AA$ were calculated. Two types of water molecules are identified in the structure and the known hydrogen bond distances used to predict the hydroxyl stretching frequencies. The data fundamentally distinguishes between two types of water according to the hydrogen bond distances, namely strongly hydrogen bonded water and weakly hydrogen bonded water. However the predicted values do not take into account factor group splitting, accidental degeneracy and in-phase and out-of-phase vibrations. The strong hydrogen bonding would suggest that the thermal decomposition of the minerals would take place at significantly high temperatures.

Some thermal studies were performed on collinsite, fairfieldite, and talmessite, and show the dehydration temperature increased with the strength of $\mathrm{H}$ bonds [35].

The variation in hydrogen bond distances as reflected in the position of the bands assigned to water stretching vibrations is reflected in the position of the water bending mode. The Raman spectrum in the $1400-1800 \mathrm{~cm}^{-1}$ spectral range (Fig. 7a) identifies water bending modes at 1632 and $1663 \mathrm{~cm}^{-1}$. The Raman spectrum shows a lack of signal, which is not unexpected as water is such a very poor Raman scatterer. In contrast, the infrared spectrum (Fig. 7b) does show considerable intensity with infrared bands found at 1621 and $1664 \mathrm{~cm}^{-1}$, confirming the variation of the hydrogen bond strength of water molecules bonded to the phosphate anion.

\section{Conclusions}

We have studied a sample of the phosphate mineral series fairfieldite-collinsite. The chemical formula can be expressed as: (Ca) ${ }_{1.99}\left(\mathrm{Mn}_{0.56} \mathrm{Mg}_{0.33} \mathrm{Fe}_{0.11}\right)_{\sum 1.00}\left(\mathrm{PO}_{4}\right)_{1.99} \cdot 2.02\left(\mathrm{H}_{2} \mathrm{O}\right)$. The mineral is an intermediate member of the series with predominance of the fairfieldite member.

The mineral is a typical phosphate mineral with all of the usual vibrations observed in the Raman and infrared spectra. Phosphate bands are observed at 925,945 and $955 \mathrm{~cm}^{-1}$ in the Raman spectrum assigned to the phosphate symmetric stretching modes. The observation of multiple bands in this spectral region supports the concept of the non-equivalence of the phosphate units in the fairfieldite structure. This concept is supported by the complexity and overlap of the infrared bands in the phosphate antisymmetric stretching region. The symmetry of the phosphate anion is reduced through bonding to water molecules. This reduction in symmetry is evidenced by the number of bands in the phosphate bending region.

Multiple bands are observed in both the Raman and infrared spectra in the $\mathrm{OH}$ stretching region. By using a Libowitzky type empirical equation which relates the wavenumber position of the $\mathrm{OH}$ stretching wavenumber in both the Raman and infrared spectra to the hydrogen bond distance, enables calculations of hydrogen bond distances for the structure of fiarfieldite. A range of hydrogen bond distances is obtained showing that water is at a range of distances in relation to the phosphate unit. This range of hydrogen bond distances contributes to the stability of the mineral.

\section{Acknowledgements}

The financial and infra-structure support of the Discipline of Nanotechnology and Molecular Science, Science and Engineering Faculty of the Queensland University of Technology, is gratefully acknowledged. The Australian Research Council (ARC) is thanked for funding the instrumentation. The authors would like to acknowledge the Center of Microscopy at the Universidade Federal de Minas Gerais (http://www.microscopia.ufmg.br) for providing the equipment and technical support for experiments involving electron microscopy. R. Scholz thanks to FAPEMIG - Fundação de Amparo à Pesquisa do Estado de Minas Gerais (Grant No. CRA APQ-03998-10).

\section{References}

[1] F.C. Hawthorne, R.B. Ferguson, Can. Min. 15 (Pt. 1) (1977) 36-42.

[2] P.D. Brotherton, E.N. Maslen, M.W. Pryce, A.H. White, Aust. J. Chem. 27 (1974) 653-656.

[3] L. Fanfani, A. Nunzi, P.F. Zanazzi, Acta Cryst. B26 (1970) 640-645.

[4] W. Joswig, E.F. Paulus, B. Liebscher, Zeit. fuer Krist. 219 (2004) 341-342.

[5] P. Keller, F. Lissner, T. Schleid, Euro. J. Min. 16 (2004) 353-359.

[6] M. Wildner, D. Stoilova, Zeit. fuer Krist. 218 (2003) 201-209.

[7] C.W. Johnston, R.J. Hill, Min. Rec. 9 (1978) 20-24.

[8] P.J. Bridge, M.W. Pryce, Min. Mag. 39 (1974) 577-579.

[9] R.L. Frost, J.T. Kloprogge, Spectrochim. Acta 59A (2003) 2797-2804.

[10] R.L. Frost, L. Duong, W. Martens, Neues Jahrb. Fuer Min. (2003) 223-240.

[11] R.L. Frost, W. Martens, P.A. Williams, J.T. Kloprogge, J. Raman Spectrosc. 34 (2003) 751-759.

[12] R.L. Frost, W. Martens, P.A. Williams, J.T. Kloprogge, Min. Mag. 66 (2002) $1063-$ 1073.

[13] R.L. Frost, P.A. Williams, W. Martens, J.T. Kloprogge, P. Leverett, J. Raman Spectrosc. 33 (2002) 260-263.

[14] R.L. Frost, P.A. Williams, W. Martens, J.T. Kloprogge, J. Raman Spectrosc. 33 (2002) 752-757.

[15] R.S.W. Braithwaite, Min. Rec. 12 (1981) 349-353.

[16] G.R. Hunt, J.W. Salisbury, C.J. Lenhoff, Mod. Geol. 3 (1972) 121-132.

[17] X.-Y. Yang, Y.-F. Zheng, X.-M. Yang, X. Liu, K. Wang, Neues Jahrb. Fuer Min. (2003) 97-112.

[18] R.L. Frost, W.N. Martens, T. Kloprogge, P.A. Williams, Neues Jahrb. Fuer Min (2002) 481-496.

[19] V.C. Farmer, Mineralogical Society Monograph 4: The Infrared Spectra of Minerals, The Mineralogical Society, London, 1974.

[20] M.E. Back, J.A. Mandarino, Fleischer's Gloss. Min. Species (2008).

[21] G.J. Brush, E.S. Dana, Am. J. Sci. Arts 17 (1879) 359-368.

[22] T.P. Moore, Min. Rec. 36 (2005) 293.

[23] M.A. Cooper, F.C. Howthorne, N.A. Ball, R.R. A., A.C. Roberts, Can. Min. 47 (2009) 1225.

[24] T. Martins, A. Lima, W.B. Simmons, A.U. Falster, F. Noronha, Can. Min. 49 (2011) 77.

[25] G.M.d. Costa, R.R. Viana, Am. Min. 86 (2001) 1053-1056.

[26] L.N. Dias, M.V.B. Pinheiro, R.L. Moreira, K. Krambrock, K. Guedes, L.A.D.M. Filho, J. Karfunkel, J. Schnellrath, R. Scholz, Am. Min. 96 (2011) 42-52.

[27] R.L. Frost, S.J. Palmer, Y. Xi, Spectrochim. Acta A92 (2012) 377-381.

[28] R.L. Frost, Y. Xi, J. Mol. Struct. 1010 (2012) 179-183.

[29] A.C. Pedrosa-Soares, C.M.d. Campos, C.M. Noce, L.C.D. Silva, T.A. Novo, J. Roncato, S.M. Medeiros, C. Castañeda, G.N. Queiroga, E. Dantas, I.A. Dussin, F. Alkmim, Geol. Soc. Spec. Pub. 350 (2011) 25-51.

[30] W. Mikenda, J. Mol. Struct. 147 (1986) 1-15.

[31] A. Novak, Struct. Bonding 18 (1974) 177-216.

[32] H. Lutz, Struct. Bonding 82 (1995) 85-103.

[33] J. Emsley, Chem. Soc. Rev. 9 (1980) 91-124

[34] E. Libowitsky, Monat. Chem. 130 (1999) 1047-1049.

[35] M. Catti, G. Ferraris, G. Ivaldi, Bull. Soc. Fran. 100 (1977) 230-236. 